\title{
Analysing the Practices of Geochemistry: Philosophical and Historical Insights \\ JEAN-PIERRE LLORED
}

Ecole Centrale Supelec

Presenting Author: jean-pierre.1lored@centralesupelec.fr

From the early metallurgy developped by alchemists to isotope geochronology, from the studies carried out in order to understand the kinetics and thermodynamics of weathering within the critical zone to very up-to-date chemical oceanography, from petrochemistry to organic geochemistry and biogeochemistry, from the scrutiny of the stratosphere to the cosmogeochemistry, geochemists have always been connecting and transforming experimental procedures, methods and principles coming from different scientific domains.

Involving philosophy of science, and especially philosophy of chemistry, as well as historial issues, this paper investigates the ways geochemists actually work and take part in the understanding of environmental issues.

Bibliography:

Berthet, Gwenaël and Renard, Jean-Baptiste « Chemistry of the Stratosphere: Metrological Insights and Reflection about Interdisciplinary Practical Networks ", in The Philosophy of Chemistry: Practices, Methodologies, and Concepts, Jean-Pierre Llored (Ed.), Newcastle upon Tyne: Cambridge Scholars Publishing, 2013, 138-154.

Bonjour, Laurence, The Structure of Empirical Knowledge, Cambridge, Massachusetts: Harvard University Press, 1985.

Brantley, S.L., Lebedeva, M., " Learning to Read the Chemistry of Regolith to Understand the Critical Zone », Annual Review of Earth and Planetary Sciences, 39(1), 2011, 387-416.

Epstein, S., "The role of stable isotopes in geochemistries of all kinds », Annual Review of Earth and Planetary Sciences, 25(1), 1997, 1-21.

Johnson, C.M., McLennan, S.M., McSween, H.Y., Summons, R.E., " Smaller, better, more: Five decades of advances in geochemistry ", Geological Society of America Special Papers, 500, 2013, 259-302.

Mayo, Deborah G., Error and the Growth of Empirical Knowledge, Chicago and London: The University of Chicago Press, 1996.

Ryan, Peter, Environmental and Low-Temperature Geochemistry, Wiley-Blackwell, $2^{\text {nd }}$ edition, 2019.

Urey, H.C., Lowenstam, H.A., Epstein, S., McKinney, C.R., « Measurement of paleotemperatures and temperatures of the upper Cretaceous of England, Denmark, and the southeastern United States », Geological Society of America Bulletin, 62(4), 1951, 399-416.

Van Schmus, W.R., Wood, J.A., "A chemical-petrologic classification for the chondritic meteorites ", Geochimica et Cosmochimica Acta, 31(5), 1967, 747-765.

White, William M., Geochemistry, Wiley-Blackwell, $2^{\text {nd }}$ edition, 2020. 